points out the importance of fields of vision, the opacity of the vitreous body and excavation; the result is dependent on all these. He never lets the patient use drops, either eserine or pilocarpine, continuously after the first operation, because of the possibility of missing the right time for the second operation in unhealed cases. The operations he employs for glaucoma simplex are:-cyclodialysis, which is particularly effective in cases of aphakia; and a similar operation called cyclodialysis plus depressio lentis. The main operation for glaucoma simplex is trephining with a modifcation concerning the incision called transcorneal trephine plus peripheral iridectomy. For inflammatory glaucoma his operation of choice is iridectomy with minor modifications.

The non-operative treatment differs in no way from that usually employed.

\title{
OBITUARY
}

\section{PROFESSOR RAMON Y CAJAL}

THE death of Ramon y Cajal should not pass unnoticed in an ophthalmological journal, for it was largely due to his pioneer work in the histology of the central nervous system that our knowledge of the histology of the retina is as complete as it is. Ramon y Cajal was born in 1852, the son of a doctor; he devoted the greater part of his life to histology and in due course his name became a household word far outside the borders of Spain. The most modest of men he valued the honours which came to him, not so much on his own account as that through him his native country was honoured. He ivas a Foreign Member of the Royal Society, Croonian Lecturer and Nobel Prizeman as well as Life Senator of Spain. His health did not allow of his meeting his ophthalmological confrères at the Congress in Madrid last year, but each member attending was presented with a beautiful little medallion of him.

\section{PROFESSOR FRITZ ASK}

WE regret to record the death in October last of Fritz Ask, of Lund, the well-known Swedish ophthalmologist. He was a member of the Editorial Board of Acta Ophthalmologica from its inception in 1924 and did very good work on myopia, the development of the lacrymal passages, treatment of dislocated lens and the vitreous, and intraocular pressure. He was also interested in military ophthalmology. In all he was the author of thirty-five papers and two monographs. 
He became personally known to his English confrères at the International Ophthalmological Conference at the Hague in 1927, when it was decided to resume the International Congresses; and he was a member of the International Ophthalmological Council.

At the jubilee of the Ophthalmological Society in 1930 Ask represented Sweden as a delegate and in the unavoidable absence, through illness. of Prof. Lundsgaard, of Copenhagen, presented addresses on behalf of the Scandinavian ophthalmologists, and made a short speech in Latin.

Cast in massive mould, Ask was one of the kindest of men. $\mathrm{He}$ will be much missed by his colleagues on the International Council and in his native land. He leaves a daughter to whom the sympathy of ophthalmologists all over the world will go out in her bereavement.

\section{NOTES}

Addenda Mr. Percival Hay writes:- " Since my description of the perforated diaphragms given in the Journal for November, Messrs. Hamblin, Ltd., have made for me an alternative in the shape of perforated discs permanently fixed in position at the back of the cells of the trial frame. They have the advantage of permanent centration, and are cheaper to manufacture."

Dr. Hagedoorn sends us the following addition to his paper, "Telangiectatic Granuloma-Botryomycosis." published in the October number:-

At my request Professor Masson was so kind as to send me his important article, which, owing to the author's stay in Canada, arrived too late to be given the attention it deserves in my paper.

After a gunshot wound in the thigh, affecting the bone, fistulae developed. The fistulous cicatrix was excised and sent to Masson for histological examination. Besides other inflammatory conditions little nodules were found. These nodules contained pus, embedding two kinds of foreign bodies: small bone sequestra and botryomycotic globules. In the pus itself free staphylococci were practically absent. Masson states that the staphylococci, killed by the action of the phagocytes elsewhere, continue to grow in the Haversian canals of the bone. If gradually the bone becomes resorbed, a membrane covers the colonies; finally the globules containing the cocci are liberated, lying free in the pus. Masson following Magrou (Thèse de Paris, 1914), speaks of a symbiotic adaptation of the cocci to the organism-host, and considers his case as the clinical confirmation of Magrou's experiments. 